\title{
Лиляна Димитрова-Тодорова
}

Българската академия на науките, София

\section{Лексикално-семантични категории теренни имена в България}

\section{1. Увод}

Поради ограничения обем в настоящото изследване ще бъдат разгледани лексикално-семантичните категории само на теренните (местностните) имена, а не на всички топоними. Независимо от някои общи черти с другите класове топоними, теренните имена се отличават от тях по известни мотивационнио-семантични особености. В изследването е използван ексцерпиран материал от всички излезли досега регионални топонимични изследвания в България.

Досега в българските ономастични изследвания са правени различни опити за класифициране на теренните (местностните) имена от редица учени, като Ив. Дуриданов [1952], Й. Заимов [1959], Н. Ковачев [1987], Л. Димитрова-Тодорова [2006; 2011] и др. на основата на предхождащи ги класификации от изтькнати слависти ономасти: F. Miklosich [1860; 1927], O. Franck [1932], P. Skok [1921], Vl. Šmilauer [1963; 1970], W. Taszycki [1946], S. Rospond [1957], H. Borek [1988], В. А. Жучкевич [1980] и др. Освен това различни видове класификации са представени във всички регионални топонимични монографии. Най-често топонимите са разпределяни в два основни типа класификации: структурно-граматична и семантична, като обаче елементи от семантиката са включвани в рамките на структурно-граматичната класификация, а формалноезикови елементи са внасяни в семантичната класификация. При това винаги едната област остава непълно представена. Затова най-целесъобразно е топонимите да бъдат включени и в двата типа класификации съобразно тематиката на класификациите. При разглеждане семантичната мотивация на топонимите за първи път в България се въвежда от Л. Димитрова-Тодорова [Димитрова-Тодорова 2006: 216-223] и по-новата разпредялба на Borek [Borek 1988: 51], която дава най-добра възможност да бъдат обхванати и откроени различните семантични типове топоними. 
Предлаганата тук семантична класификация на теренните имена показва богатството от типове теренни имена Тя се различава от класификациите на другите класове топоними. Въз основа на произхода на теренните имена (т.е. от какъв вид име са образувани) и мотивите на номинация се открояват две основни групи и голям брой подгрупи названия: А. Деапелативни, деадективни, деадвербативни теренни имена, имена денумералии или имена, произлезли от междуметие. Б. Депроприални теренни имена: деантропонимични и детопонимични (релативни имена според терминологията на H. Borek [ibidem: 51]).

\section{2. Деапелативни, деадективни, деадвербативни теренни имена, имена денумералии или имена, произлезли от междуметие}

Деапелативните, деадективните и др. типове теренни имена се делят на: I. Топографски имена, наричани от различните ономасти още земеписни имена, физико-географски имена, имена според природните условия. II. Имена във връзка с човешката дейност, наричани още културни имена или културно-исторически имена.

Към топографските имена спадат: 1 . Имена от географски термин: Бър чината, Ва̀лозите, Вѐждата, Длъбнѝко, Дола̀, Лъкѝте, Могѝлките, Низина̀ma, Падйната, Равнѝще, Чу̀ката и мн.др. 2. Имена от названия на почви и минерали или във връзка с техния цвят: Белѝлката, Бѐлия ка̀мък, Гнѝлнициите, Ка̀менеи, Кариѐрите, Пръстнйu̧ата, Сѝнята пръст, Сѝпея и др. 3. Имена от названия на растения и дървета: Брѐстите, Бу̀ковц̧а, Бъззето, Въ’рбалакът, Габра̀ка, Га̀бъра, Гло̀а и др. 4. Имена във връзка с отсъствието на растителност: Го̀леш, Голешйна, Го̀ли връх, Го̀ли рид, Го̀ло бъ’рдо, Лйсец, Плешиेвец и др. 5. Имена от названия на птици, животни и техни обиталища: Въ̊лча ду̀пка, Га̀рван дол, Ко̀нската могѝла, Лисѝчени ду̀пки, Свѝнища, Сърнево и др. 6. Имена според особения вид на местността или на обект в нея: Висо̀ка могйла, Дълбо̀кия трап, Крѝва, Острѐu, Око̀лчеста лива̀да, Побѝен ка̀мик и др. Към разглеждания тук тип теренни имена спадат и имената, възникнали в резултат на метафоричен пренос, когато «наименованието на един или друг предмет или явление се пренася върху друг предмет или явление по силата на тяхното сходство, по съвпадение на един или друг признак» [Шмелев 1964: 57-58]: Вѐждата, Гава̀низа, Диса̀zите, Камѝната, Качу̀ля, Престо̀ла, Пу̀шката, Стъпката, Трѐnезник, Ша̀пка и др. 7. Имена по местоположение спрямо други обекти: Го̀ник, До̀лното калѐ, Зад байря, Кра̀йни рид, Между па̀тищзата и др. 8. Имена по положение спрямо сльнцето (огрятост - неогрятост): Гюнѐто, Мразлѝв дол, Осо̀ица, Пеклѝųа, 
Печенѝко, Припека̀вището, Присо̀е, Усо̆йната и др. 9. Имена във връзка с атмосферни явления: Блъснатия чука̀р, Бу̀рьово, Вя̀тровица, Громъ, Гърдобйката, Убѝт кава̀к и др.

В българската топонимия след групата на топографските названия важно място заема и групата на културните названия, които със своето разнообразие са огледало на дейността на човека в природата, и по-конкретно на неговата битова, стопанска дейност през различните исторически периоди, част от която е свързана с неговия религиозен мироглед или с неговата духовна култура.

В зависимост от разнообразието на стопанската и културно-историческата дейност на хората и нейното отражение върху топонимията в България групата на културните топоними се разделя на няколко групи и подгрупи. 1. Имена във връзка със земеделието - основен поминък на българите в миналото. 1.1. Имена във връзка с вида на работната земя: Голя̀мата нѝва, Нѝвата, Нѝвичката, Орнѝцата, Паза̀рска орнѝща, Тарла̀та и др. 1.2. Имена във връзка с начина за получаване на работната земя: а) чрез изсичане и изкореняване на горите: Копа̀ците, Корена̀ка, Коренѐжа, Ло̀мището, Пъна̀кът, Сѐчена корѝя, Треба̀кът, Чйстеното и др. Съществува и една група теренни имена, създадени във връзка със запазването на горите: Бра̀нища, Бра̀нище, Бра̀нището от бра̀нище 'гора, забранена за изсичане' и др. б) чрез опожаряване на горите: Горела̀ка, Огорѐното, Опа̀леното, Палена̀кът, Пожара̀ко, Пърла̀ка, Угорѐлеи и др.; в) чрез разораване на нови земи: Новинйте, Но̀вите нйви, Целина̀та, Целинйте и др.; г) чрез оставяне за няколко години неплодородната земя да почива, без да е обработвана: Голѐма орнѝц $а$, Орнйцата, Орнича̀к, Орнича̀ко и др.; д) чрез наторяване на нивите: Гнойще, Торищяа, Торѝщето, Торна̀та нйва, Торнѝщата, Торо̀вииа, Широ̀кото торѝще и др.; е) чрез разораване: Плу̀говината, Плуेговините, Плужница, Плужнииата, Плуे овасъ 'поле за плуг' и пр.; ж) чрез разделяне на земята на дребни участъци поради частната собственост: Делнѝчите, Кра̀йчето, Леха̀та, Парца̀лчетата, Париѐлите, Парчѐтата, Първви уча̀сток, Вто̀ри уча̀сток и др. Тук могат да бъдат отнесени и имената на местности, получени въз основа на разграничаване на отделните парцели земя чрез поставянето между тях на гранични знаци от типа на храсти, плетове, забити колове, камъни и др.: Висоेкия слог, Межда̀ка, Межда̀та, По̀чката, Сѝнурът, Сло̀га, Широ̀ките сйнори и др.; з) чрез уедряване на земите, чрез обединяването им в трудовокооперативни земеделски стопанства (ТКЗС) в близкото минало: Бло̀ка, Вѐднината, Вѐдничкото, Кооператѝвната нйва, Орта̀шкото и др. 1.3. Имена във връзка с вършитбата на житни култури: Беглѝшкия харма̀н, Вѐхтия ток, Гу̀мнища, Гу̀мното, Гу̀мощник, То̀ка, Ха̀рманлъка и др. 1.4. Имена във връзка с типа земеделска култура, засявана в именувания обект: Бобенището, Гра̀ховете, Ечмѐнището, Жйтнииата, Карто̀фище, Лѐненище и др. 1.5. Имена във връзка с вида на засажданите места: Бахчѝите, Боста̀на, Градѝната, 
Зеленчу̀ковата градѝна, Ла̀хналъка, Разса̀дника и пр. 2. Имена във връзка с овощарството и с вида на плодните насаждения: Ово̀иките, Приेсадите, Фйданлъка, Кру̀шите, Слива̀ка, Череша̀ка и др. 3. Имена във връзка с лозарството: Вѝнена могѝла, Гроेзден, Лоза̀та, Ло̀зето, Мара̀шите, Ма̀точника, Нерезйи и др. 4. Имена във връзка с розарството: Гю̀ловете, Ро̀за, Ро̀зова долина̀ = Долина̀та на ро̀зите, Розова̀рната, Ро̀зовеи, Ро̀зово, Ро̀зов кла̀денеи и др. 5. Имена във връзка със скотовъдството. 5.1. Имена във връзка с вида на местата за паша на добитька и на местата, които служат за фуражна база: Волова̀рската мера̀, Косенѝната, Лива̀дата, Лйстника, Мера̀та, Па̀рковото па̀сище, Па̀шата, Пладнйщето, Сена̀рката и др. 5.2. Имена във връзка с хранилки, солища и водопой: Водопо̀ите, Корита̀та, Кърмѝлото, На̀nоите, Пойлата, Солѝщето, Хра̀нищата и пр. 5.3. Имена във връзка с местата за минаване на добитъка, по заграждения, за да не избягат пасящите животни и др.: Вра̀тникът, Заградѐното, Мину̀шката, Огра̀дето, Про̀каpa, Про̀леза, Проммката, Стъргата и т.н. 5.4. Имена във връзка с различни домашни животни: Бивола̀рски рът, Коेзница, Говѐжди пътѐки, Ко̀нското, Мага̀решко бърддо, Свйнски дол и др. 5.5. Имена във връзка с помещенията за добитька, предимно в планините, с помещенията, в които се произвеждат млечни продукти или които са предназначени за пазачи на добитък: Бачѝще, Гра̀ждовете, Кашкава̀лницата, Коша̀рите, Къила̀та, Ма̀ндрата, Пъда̀рницата, Хлѐвището и др. Една част от тях са топоними, с които са наименувани кошари за конкретни видове домашни животни: Бивола̀рника, Говеда̀рника, Крава̀рника, Овча̀рника, Свина̀рника, Телча̀рника и др. 6. Имена във връзка с пчеларството: Ко̀шерен, Меда̀рнята, Пчела̀рско по̀лье, Пчелиेнище, Пчелиेнски рът, Пчѐлнико и др. 7. Имена във връзка с бубарството: Буба̀рник, Буба̀рника, Буба̀рнико, Буба̀рниците, Пашку̀лнииата и др. 8. Имена във връзка с лова: Авджййската чешма̀, Ло̀вна лъка̀, Ло̀вна спѝрка, Ло̀вната хѝжа, Ловната чешма̀ и др. 9. Имена във връзка с риболова: Риба̀рника, Риба̀рииа, Риба̀рии, Рйбен, Рйбник, Рѝбното ѐзеро и пр. 10. Имена във връзка със занаятите. 10.1. Имена във връзка с воденичарството, широко застьпено в миналото в бита на хората: Бѐнта, Ва̀лияовата воденййа, Жѐрката, Жъриньовнииа, Караджѐйката, Кѐлевата воденййа, Мѐлнииата и др. 10.2. Имена във връзка със занаятите, свързани с водната сила: Валёвиųите, Точѝлото, Ча̀рковете и др. 10.3. Имена във връзка с рударството: Bùzнището, Мада̀на, Пла̀вило, Плака̀лница, Ру̀дищата, Самоко̀вището, Сгу̀рището и др. 10.3.1. Имена във връзка с добивания метал: Златѝца, Зла̀тието, Бакъра, Срёбърна долчѝна, Желѐзнииа, Медѐт и пр. 10.4. Имена във връзка с добива и преработката на дървесина - Бичкиджййницата, Вла̀чището, Дърва̀рския път, Дъскорѐзницата, Сѐчището, Стру̀жната, Та̀лпата и др. 10.5. Имена във връзка с въглищарството: Въглища̀рски дол, Га̀рище, Жйжните, Куйята, Курѝло, Кюму̀рица, Ту̀рлата, Щѐтина и др. 10.6. Имена във връзка с производството на барут: Бару̀тнииата, Бару̀т дерменй, Ба- 
рутчййницата и др. 10.7. Имена във връзка с грънчарството: Гръинчевица, Грънча̀рите, Грънча̀рница, Чо̀млекчия и др. 10.8. Имена във връзка с производството на вар - Вараджййниц̧ата, Варджѝйниците, Варенйц̧а, Кирѐчницуата, Кирпѝча и др. 10.9. Имена във връзка с производството на катран: Катранджййка, Катранджѝйски дол, Катранджйкя, Катранджѝйското, Катра̀нцата и др. 10.10. Имена във връзка с каменарството, добива на пясък, пръст и глина: Гнѝлника, Ка̀менната кариѐра, Каменоло̀мната, Мѐката кариѐра, Пръстницата и др. 10.11. Имена във връзка с търговията: Бажда̀р, Паза̀рския път, Търго̀вска нѝва, Търго̀вското, Чаршѝята и др. 10.12. Имена във връзка с ковачеството и подковачеството - Ковачѝца, Налбантла̀ри, Налба̀нтовата и др. 10.13. Имена във връзка с коларството (арабаджийството) и кираджийството (превозване на стоки с кон или кола): Арабаджѝ даяма̀, Кола̀рево, Кола̀рката, Кола̀рския път, Кола̀риа; Кираджѝйския мост и др. 10.14. Имена във връзка с производството на тухли, керемиди и цигли във връзка със строителството: Керемидийинияата, Кермида̀рка, Кирпичлиेка, Тухла̀рната, Цигла̀рницата и др. 10.15. Имена във връзка със строителството: Дюлгѐря, Дюлгѐрска бачѝа, Дюлгѐрска воденѝuฺ, Дюлгѐрски орнйuи, Зида̀ричи и др. 10.16. Имена във връзка с кожарството - Табакхана̀та, Табаханѝте, Таба̀u̧ите, Таба̀шки мост, Шо̀пова таба̀н и др. 10.17. Имена във връзка с даракчийството: Дара̀ка, Дара̀ков мост, Дара̀uฺте, Дара̀шка ва̀да и др. 10.18. Имена във връзка с производството на седла: Самарджѝйското, Сара̀ча, Сара̀чкио кла̀денец, Сара̀чкото, Сара̀шка корѝя и др. 10.19. Имена във връзка с производството на казани: Казанджййниц̧ата, Казанджййски дол, Казанджййското и др. 10.20. Имена във връзка с клането на добитък: Каса̀nник, Каса̀nнята, Каса̀nски дол, Каса̀nското, Кла̀ниц̧ата, Са̀лханата и др. 10.21. Имена във връзка с други занаяти, застъпени по-слабо в теренните имена, за част от които съдим по прякорите, от които са образувани топонимите: а) производство на свредели: Бу̀ргуджийката и др.; б) гребенарство: Гребена̀рката; в) медникарство: Бакърджѝ гъол 'медникарска локва' и др.; г) калайджийство: Калайджййската чешма̀, Каладжѝска лива̀да и др.; д) производство на каци: Кац̧а̀рницата, Каца̀рска махала̀ и др.; е) производство на гайтани: Гайтанджййницата и др.; ж) производство на сапун: Сапунджѝска ба̀ра, Сапунджѝски дол, Сапунджййското.

Към тази сравнително голяма група имена влизат и такива по други редки занаяти. 11. Имена във връзка с постройки и съоръжения на човешката дейност, като порти, огради, единични къщи и пр.: Bра̀тнята, Канто̀на, Колѝбата, Огра̀днята, Пирамѝдата, Плетнѝк, Ста̀рата плѐвня, Чарда̀ка, Ха̀нчетата, Шосѐто и др. 12. Имена във връзка с пътища, пътни съоръжения, крайпътни наблюдателни постове, бродове и пр.: Беклемѐто, Бѐров брод, Ва̀рдата, Гечѝта, Кона̀чето, Летѝщето, Мо̀стчето, Но̀вия път, Пъ̀теката, Стра̀жица, Стъ̀лбите и др. 13. Имена във връзка с исторически и археологически обекти, укрепления и пр.: Градѝще, Истика̀мите, 
Калѐто, Крепостта̀, Метирѝза, Око̀пите, Па̀метника, Та̀бята, Хисарлъка и др. 14. Имена във връзка с гробове, гробища, некрополи и лобни места: Бра̀тската могѝла, Гробищата, Гроббииата, Латѝнския гроб, Ма̀шатлък, Меза̀ра, Тюлбѐто и др. 15. Имена във връзка със случки и събития: Войнѝшка корѝя, Гърмѐния блок, Закла̀ния човек, Заклѐтата корѝя, Мо̀мина стена̀ и др. 16. Имена във връзка с култови обекти - черкви, манастири, параклиси, кръстове, оброчища и пр.: Джсамййския мост, Кръста, Ла̀зарнята, Манастѝр, Мусала̀ таш, Обро̀ка, Светй Илѝя, Текѐто, Черко̀вището и др. 17. Имена във връзка с легенди, предания, религиозни представи: Джѝнов дол, Змѐйова ду̀пка, Има̀нето, Къेрвавия дол, Ма̀ркова стъ்пка, Русалййски гроббщща и др. 18. Имена във връзка с обществени движения - религиозни или съпротивителни: Богомѝлски грӧбщща, Бу̀нкера, Комѝтски ко̀рдел, Партиза̀нска пещера̀, (Х) арамйя и др. 19. Имена във връзка с поселищните отношения в миналото, свидетелстващи за наличието на селища в миналото: Вѐтото сѐло, Градѐu, Дво̀рища, Пустосѐл, Ста̀ри юрт, Ста̀рото сѐлище и др. 20. Имена във връзка с поземлени отношения в миналото: Бёйските нѝви, Ва̀кувската мѐлница, Кавгалййски уча̀сток, Казиоेнното, Чифлиेкя и др.

\section{3. Депроприални теренни имена: деантропонимични и детопонимични (релативни имена)}

Деантропонимичните теренни имена се делят на няколко групи: 1. Имена от единични антропоними - посесивни и паметни (мемориални). 2. Имена от събирателни антропоними, произлезли от антропоним. 3. Имена от събирателни антропоними, произлезли от апелатив.

1. Теренните имена или т.нар. посесивни теренни имена от единични антропоними много добре представят частнособственическите отношения в миналото, които след политическите промени през 1989 г. отново се възстановяват в България. Те най-често носят в себе си името на собственика на местността, която именуват, или името на собственика на обект в нея. Този тип имена са многобройни и се делят на няколко групи имена: 1.1. Изцяло от лично име: Братва̀на, Бу̀гдана, Гергѝна, Димитра̀ш, Дра̀гни, Кръстйна, Па̀вля и др. 1.2. Изцяло от прякор: Бурма̀та, Гъззетата, Ка̀раджата, Ко̀бакчията, Ко̀зар, Късърар, Саму̀ра и др. 1.3. По андроним: Ба̀бината Йорда̀нчина нйва, Васѝлица = Васйлината нѝва, Га̀ньовчината нйва, Да̀скалчината башчѝя, Ма̀рковчина гроб и др. 1.4. По лично име: Ба̀ньов ка̀мък, Алѐксьовата къщичка, Андоेновия боа̀з, Андрѐйовите кошѐри, Ба̀ньов ка̀мък, Бѐлчовото пладнйще и др. 1.5. По прякор: Бъ( Да̀скаловата воденѝча, Да̀скаловата гора̀, Костѝлковото ло̀зе, Пипѐрьова- 
та воденйца, Сланиेнкова чайр и др. 1.6. По фамилно име: Коджа̀овата воденѝца, Коджа̀ Сланйнковата лива̀да, Ко̀лчовата корѝя, Ко̀тьоолу, Са̀рова mpan и др. 1.7. Паметни (мемориални) имена: Караджа̀та, Ста̀мо Ко̀стов. Тези имена са сравнително малко. Най-често с тях се именуват железопътни кантони в полето. 2. Теренни имена от събирателни антропоними по родово име: Бёберев кула̀к, Ва̀нкоолте нѝви, Дра̀говската чешма̀, Коза̀ровския кула̀к, Тойовската могйла и др. 3. Теренните имена от събирателни деапелативни антропоними се делят на няколко групи имена: 3.1. По етноними: Бѐджане, Влах тарла̀, Кара̀качени = Кара̀каченските колѝби, Кума̀нща, Македоेнското, Тата̀рските нѝви, Ту̀рската бозалъчка, Черкѐзки ниेви и др. 3.2. По служебни (професионални) имена: Бѝрниковата кру̀ща, Бака̀лската махла̀, Белбѐр пуна̀р, Даулджиेито и др. 3.3. От жителски имена: Гору̀нни, Дѐрнени, Ра̀щени. Последните теренни имена са старинни. Те показват, че назоваваните с тези имена местности са били в миналото населени места.

Детопонимичните теренни имена също биват няколко типа: дехидронимични, деойконимични и деоронимични. Те също се делят на няколко групи: 1. Подновени имена с метонимична функция, възникнали в резултат от промяната или разширяването обсега на името върху съседни обекти: Колокоेч (река) > Колокоेч (връх). 2. Пренесени имена от по-рано назован друг обект поради някаква прилика с него, т.е. имена с метафорична функция: Добруджа (плодороден район в Североизточна България) > Добруджа (местност с плодородни ниви). 3. Имена с диференцираща функция: Горния Cònom и Доллия Cònom. 4. Имена с локализираща функция, която служи за определяне положението на новоназован обект спрямо друг вече назован обект: Над Ба̀лко, Зад Укра̀йна, Под Го̀рник. 5. Паметни (мемориални, наричани още и възпоменателни) имена - пренесени в памет или в чест на място, свързано с историческо събитие или с друго емоционално съдържание: Октомврийска революиия, Пѐткова бу̀нкер. 6. Вторично възникнали имена чрез структурно преоформяне на теренни имена или на друг тип топоними: Добросѐл > Добросѐлската могйла, Елѐново > Елѐновския блок и др.

В особени групи могат да бъдат отделени имената от: 1. Изчезнали апелативи или прилагателни: Джу̀zела - от изчезнало нарицателно джу̀гел 'чукара', запазено като нарицателно само под формата джуглина със същото значение; Свещй плаз - пьрвият компонент е от изчезналото днес прилагателно свещй от апелатива свещ. 2. Изчезнали значения на живи думи в говора: Песнйца - от апелатива пес с изчезнало днес значение, който днес се използва само със значение 'куче'. 3. Редки живи думи в говора: Теклѝиата - от апелатива теклѝиа 'жилава земя', запазен в говора, но изчезнал в други говори от страната. 4. Изчезнали лични имена в района или в страната: Димитра̀м - от изчезнало лично име Димитра̀м, чиято основа е запазена в личното име Димитра̀шко; Доткко тарла̀ по изчезнало лично име, производно от рядко срещаното днес име Дото. 5. Изчезнали прякори: Костѝл- 
ковото ло̀зе - от изчезнал прякор Костѝлката, от който е фамилното име Костѝлков от друг регион. 6. Изчезнали родови имена: Тоташла̀р - от изчезнало родово име Тоташла̀р, което е по прякор.

В отделни групи могат да бъдат отнесени двузначните и многозначните теренни имена, имената с несигурна или с неясна етимология, както и имената от чужд произход, заемки, калки и полукалки.

\section{4. Заключение}

Обособяването на семантичните категории теренни имена в отделна група е обусловено от онимичната специфика на топонимите и от свързаната с нея мотивация в акта на назоваването. Всеки топоним възниква въ3 основа на присьщ за назовавания конкретен обект мотивиращ белег и при семантичната мотивационна класификация се откроява ясно мотивационната връзка между топонима и назовавания обект.

\section{Библиография}

Димитрова-Тодорова Лиляна, 2006, Местните имена в Поповско, София.

Димитрова-Тодорова Лиляна, 2011, Собствените имена в България. Изследвания, анализ, проблеми, София.

Дуриданов Иван, 1952, Местните названия от Ломско, София.

Заимов Йордан, 1959, Местните имена в Пирдопско, София.

Жучкевич Вадим Андреевич, 1980, Общая топонимика, Москва.

Ковачев Николай, 1987, Българска ономастика. Наука за собствените имена, София.

Шмелев Дмитрий Николаевич, 1964, Очерки по семасиологии русского языка, Москва.

Borek Henryk, 1988, Nazwy relacyjne w toponimii, [in:] V Ogólnopolska konferencja onomastyczna. Poznań 3-5 września 1985, Poznań, 43-51.

Franck Otto, 1932, Studien zur serbokroatischen Ortsnamenkunde, Berlin.

Miklosich Franz, 1927, 1860, Die Bildung der slavischen Personennamen. Die Bildung der Ortsnamen aus Personennamen im Slavischen, Heidelberg.

Rospond Stanisław, 1957, Klasyfikacja strukturalno-gramatyczna słowiańskichnazw geograficznych, Wrocław.

Skok Petar, 1921, Prilozi k ispitivanju srpsko-hrvatskich imena mjesta, Zagreb.

Šmilauer Vladimir, 1963, Ůvod do toponomastiky, Praha.

Šmilauer Vladimir, 1970, Přiručka slovanské toponomastiky, Praha.

Taszycki Witold, 1946, Stowiańskie nazwy miejscowe (ustalenie podziatu), Kraków. 


\section{Liljana Dimitrova-Todorova}

\section{Topical classification of semantic category of place names in Bulgaria}

\section{(Summary)}

This paper deals with lexical-semantic categories of place names in Bulgaria which distinguish from the other categories of toponyms by some motivation-semantic characteristics. On the basis of the origin of the place names and the denomination motivation are differentiated two main groups and many subgroups of names. The first main group includes place names derived from appellatives, adjectives, adverbs and numeratives. Two types of names are differentiated here: topographical and cultural, which split into a large number of subtypes. In the second main group are included the place names from proper names which also have two basic types of place names from anthroponyms and from toponyms to which refers a number of subtypes. Many other semantic categories of place names exist too, among which are the single meaning and double meaning names, the names with uncertain or unclear etymology, the loans translation and others.

Słowa kluczowe: nazwy terenowe, toponimy, motywacja nazwotwórcza, kategorie semantyczne.

Key words: place names, toponyms, denomination motivation, semantic categories. 